\title{
GURU PENDIDIKAN ISLAM DALAM KONSEP 5M
}

\author{
Rahmad Fauzi Lubis \\ STAI Diniyah Pekanbaru \\ Jl. Kuau No. 01 Sukajadi Pekanbaru \\ rahmad.fauzi48@gmail.com
}

DOI: /10.46781/al-mutharahah.v17i2.158

\begin{abstract}
Research in the concept aims to see Islamic education teachers in the $5 \mathrm{M}$ concept and the opinions of Islamic education experts in a concept that is able to deliver a teacher to become a role model in order to achieve educational goals. This research is qualitative research. Much memorable Islamic education has to do with the teacher. Smart teachers will produce smart students, the foundation for the development of Islamic education teachers itself is important to produce a memorable educator. In this study, we will discuss the characteristics of Islamic education teachers based on the $5 \mathrm{M}$ concept.
\end{abstract}

Keywords: Teacher, Islamic Education, 5M Concept

\begin{abstract}
Abstrak
Penelitian in ibertujuan untuk mengetahui ciri guru pendidikan islam dalam konsep 5M mengetahui konsep dan pendapat para pakar pendidikan islam mengupas sampai mendalam konsep yang mampu mengahantarkan seorang guru menjadi sosok panutan demi mencapai tujuan pendidikan. Penelitian ini merupakan penelitian Kualitatif. Pendidikan islam yang berkesan banyak terkait dengan diri guru. Guru yang cerdas akan menghasilkan siswa yang cerdas, tumpuan terhadap pembangunan guru pendidikan islam itu sendiri adalah penting untuk menghasilkan seorang insan pendidik yang berkesan. Dalam kajian ini kita akan berbicara dalam pembahasan cirri guru pendidikan islam berdasarkan konsep 5M.
\end{abstract}

Kata Kunci: Guru, Pendidikan Islam, Konsep 5M

\section{A. PENDAHULUAN}

Proses pembelajaran adalah tanggung jawab seorang guru dalam mengembangkan seluruh potensi yang ada pada siswa. Komponen salah satu yang diharapkan dan yang akan menjadi sasaran adalah bagaimana pembelajaran yang disajikan guru dalam kelas. Maka proses dari itu semua diharapkan mengubah tingkah laku siswa baik dari aspek tingkah laku maupun intelektual.

Pendidikan merupakan hal yang penting dalam kehidupan manusia karena pendidikan itu sendiri merupakan yang terpenting dalam hidupnya. Manusia tidak terlepas dari pendidikan dari seluruh bagian hidupnya baik lingkungan, masyarakat, sekolah, rumah tangga, bahkan pendidikan sudah dimulai dari sejak kandungan. Pendidikan bagi manusia merupakan pedoman makna hidup, cahaya penerang untuk mencapai arah tujuan hidup yang sesungguhnya untuk mencapai kebaikan didunia dan akhirat. Mengembangkan kperibadian dan kreatifitas yang dibimbing oleh orang yang sadar baik dalam pendidikan formal atau non formal adalah merupakan salah satu hakikat pendidikan ${ }^{1}$

Manusia sejak dalam kandungan sudah diberikan pendidikan oleh orangtua untuk anak agar kelak anaknya mudah dibimbing dalam ilmu agama. Karena kepribadian anak itu sangat dipengaruhi seberapa banyak ia tahu tentang ilmu agama. Usaha memperkokoh iman sangat

\footnotetext{
${ }^{1}$ Halstead. Towards (A Unified View of Islamic Edacuation. Vol.6.No.1, 1995) hlm. 40.
} 
diperlukan agar senantiasa taqwa disisi Allah SWT. Sesuai dengan keyakinan atau agama yang dianut masing-masing anak didik dalam menciptakan insan yang beriman.

Di Negara kita Indonesia, pendidikan agama dapat diperoleh melalui tiga jalur, yaitu formal, nonformal dan informal. Pendidikan formal merupakan jalur pendidikan yang terstruktur yang terdiri atas pendidikan dasar, menengah, dan perguruan tinggi. Pendidikan nonformal adalah jalur pendidikan di luar jalur pendidikan formal yang dapat dilaksanakan secara terstruktur dan berjenjang. Sedangkan pendidikan informal adalah jalur pendidikan keluarga dan lingkungan.

\section{B. METODE PENELITIAN}

Metode penelitian yang digunakan penulis dalam penelitian ini adalah situdi literature review. Sedangkan pendekatan yang penulis lakukan adalah pendekatan kualitatif. Adapun Metode kualitatif merupakan prosedur penelitian yang menghasilkan data deskriptif yaitu berbentuk kata-kata tertulis atau penuturan dari lisan seseorang dan perilaku yang dapat diamati. Teknik pengumpulan data yang penulis kumpulkan yaitu dengan cara menggunakan buku, jurnal, scopus, dan lain-lain. Teknis analisis data yaitu semua data dianalisis untuk disajikan dalam bentuk jurnal secara konperhensif dan terstruktur.

\section{PEMBAHASAN}

\section{Karakteristik Guru Pendidikan Islam}

Tugas dan tanggungjawab guru sebenarnya sudah lama dikaji dan menjadi perbincangan oleh para tokoh. Salah satunya Hossein Nasr beliau mengemukakan bahwa guru dalam perspektif islam memiliki peran dan tanggungjawab yang sangat urgen dalam pembangunan ahlak yaitu sebagai murabbi a trainer of souls and personalitiesdan tidak hanya sekedar menjadi mu'allim a transmitter of.knowledge.

Begitu juga dengan pendapat Rosnani Hashim beliau mengatakanbahwa seorang guru itu harus menjadi muaddib, yaitu seorang yang bisa menanamkan adab, displin dalam pemikiran, fisikal maupun rohani. Halstead juga menjelaskan bahwa guru sangat dihormati dan dimulyakan karena bukan saja berilmu akan tetapi karena memiliki keperibadian dan komitmen yang sangat tangguh dalam islam dan mampu menjadi tauladan kepada para anak didiknya sehingga anak didiknya bisa mencontoh guru mereka dengan ketauladanan yang sangat tinggi ${ }^{2}$.

Pendidik itu perlu berwibawa karena kewibawaan pendidik muslim itu sangat urgen dan penting dalam mentransfer ilmu pengetahuan dan menjadi model bagi siswanya. Mestinya seorang guru meniru keunggulan dan keluhuran Rasulullah SAW dalam mendidik siswanya. Paling tidak minimal ada lima komponen yang dicapai agar menjadi ciri guru muslim yaitu, mudarris, muaddib, mursyid,dan mu'allim disingkat dengan 5M.

Dalam pembahasan mengenai konsep guru dan peranan guru sebelum ini terdapat beberapa isu yang sangat penting untuk dibahas. Khususnya yang berkaitan dengan guru pendidikan islam semasa didalam atau diluar. Adapun usaha yang dilakukan guru bisa dikelompokkan kepada komponen 5M, yaitu mudarris, muaddib, murabbi, mursyid dan mu'allim. Konsep ini kemudian pada dasarnya dibina husus kepada guru pendidikan islam, namun juga bisa diaplikasikan kepada guru lain dengan dilakukan beberapa modifikasi kecil.

Dari beberapa upaya penting ini berdasarkan konsep 5M yang mesti diamalkan seorang guru dalam pembelajaran didalam dan diluar kelas dibincangkan dalam pembahasan berikut ini.

${ }^{2}$ Hashim Rosnani. Educational Dualism in Malaysia. (Kuala Lumpur: Oxford University Press, 1996.) hlm. 53. 


\section{a. Mudarris}

Kata mudarris bermakna pengajar yang berasal dari kata kerja darosa atau tadris yang dimaknai belajar atau pelajaran. Menurut Lane darosa ghairuhu dimaknai sebagai he made another to read or to readrepeatedly or tostudy in order to remember or to read and lear he taught him to read he lectured him ${ }^{3}$. Perkataan mudarris atau tadris tidak disebut secara langsung dalam Al quran sebaliknya perkataan darosa atau belajar dan mempelajari terdapat dalam tiga ayat Al quran sebagai berikut.

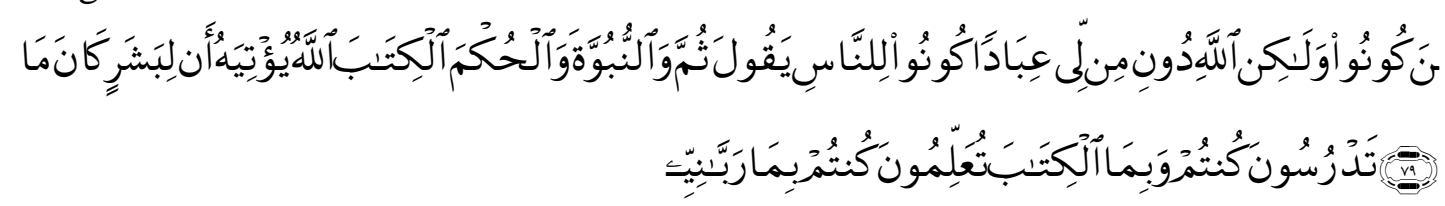

Artinya: Tidak wajar bagi seseorang manusia yang Allah berikan kepadanya Al kitab, hikmah dan kenabian, lalu dia Berkata kepada manusia: "Hendaklah kamu menjadi penyembah-penyembahku bukan penyembah Allah." Akan tetapi (Dia berkata): "Hendaklah kamu menjadi orang-orang rabbani, Karena kamu selalu mengajarkan Al Kitab dan disebabkan kamu tetap mempelajarinya. (QS. Ali Imran, 79)

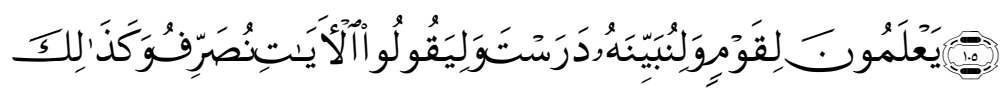

Artinya: Demikianlah kami mengulang-ulangi ayat-ayat kami supaya (orangorang yang beriman mendapat petunjuk) dan supaya orang-orang musyrik mengatakan: "Kamu Telah mempelajari ayat-ayat itu (dari ahli Kitab)", dan supaya kami menjelaskan Al Quran itu kepada orang-orang yang Mengetahui. (QS. Al An'am, 105)

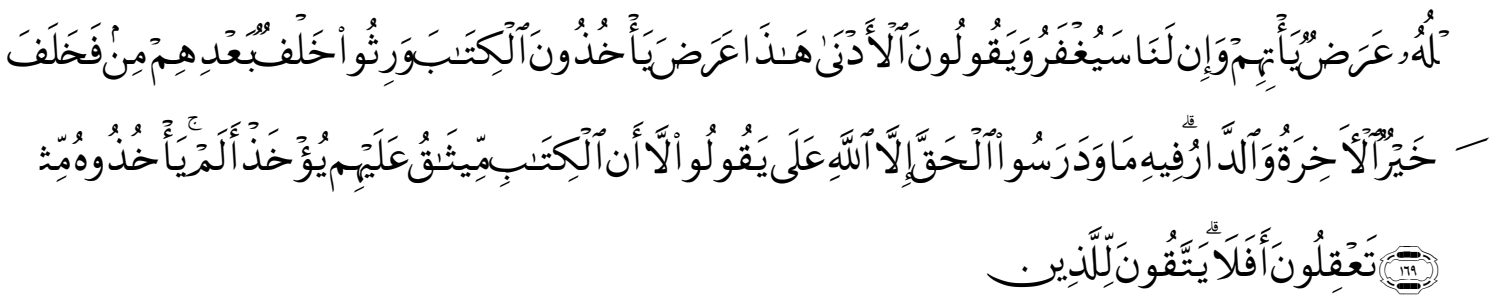

Artinya : Maka datanglah sesudah mereka generasi yang jahat yang mewarisi taurat yang mengambil harta benda duniawi yang rendah ini, dan berkata, kami akan diberi ampun, dan kelak jika dating kepada mereka harta benda dunia sebanyak itu pula niscaya mereka akan mengambilnya juga. Sudahkah perjanjian taurat sudah diambil dari mereka, yaitu bahwa mereka tidak akan mengatakan terhadap Allah kecuali benar, padahal mereka telah mempelajari apa yang disebut didalamnya? Dan negeri akhirat itu lebih baik bagi mereka yang bertaqwa, maka apakah kamu sekalian tidak mengerti? (QS. Al A'raf, 169)

Dari beberapa ayat tersebut yang sudah kita tuliskan semakin jelaslah bagi kita bahwa peran guru sebagai mudarris ini begitu istimewa sehingga Allah SWT menyinggungnya dalam al quran dibeberapa ayat. Mudarris dikonsepkan kepada seorang guru mulia yang bersumber dari alquran dan hadis. Dalam konteks pembahasan $5 \mathrm{M}$ ini peranan mudarris merujuk kepada 25 ciri berikut ini: 

1) Aktif dalam mengajar
2) Menulis dengan baik dan jelas
3) Membuat penilaian pormatif
4) Membuat rumusan pembelajaran
5) Memberikan tugas pekerjaan rumah
6) Bisa menarik perhatian siswa
7) Membuat struktur pengajaran
8) Bisa mengaitkan pembelajaran dengan keadaan ril
9) Memperkenalkan tunjuk ajar pembelajaran
10) Tepat serta jelas menyampaikan materi
11) Berkesan dalam menulis
12) Memperhatikan minat siswa
13) Memperkaya sumber serta meluaskan wawasan
14) Suasana kondusif dalam mengawal pembelajaran
15) Bisa menggunakan bahan bantu ajar dengan baik
16) Memiliki sifat humor agar siswa tidak terlalu tegang
17) Memiliki kemahiran interpersonal yang baik
18) Menguasai metodologi dengan baik
19) Mempergunakan berbagai teknik bertanya saat pembelajaran
20) Menjawab petanyaan siswa dengan hikmat
21) Mengesan masalah pembelajaran siswa
22) Menjarakkan pembelajaran
23) Mengajar mengikuti urutan sesuai yang ada didalam buku
24) Member peneguhan kepada siwa selama pembelajaran
25) Melakukan intropeksi atau evaluasi terhadap diri sendiri ${ }^{4}$.

\section{b. Muaddib}

Kosa kata muaddid berakar dari addaba yuaddibu ta'diban, yang dimaknai sebagai pembentuk adab ataupun karakter yang baik dengan artian kata membersihkan seseorang dari suul adab atau dari kotoran. Mendidik anak dengan adab tarbiyah dan soleh serta terbebas dari amal keji dan munkar jega bagian dari Ta'dib Al-Sibiyyin. Kalau kita mencoba mencari pengertian ta'dib dari segi terminology maka dia diartikan proses melatih untuk berahlakul karimah. Jadi seorang individu yang terdidik yang memiliki potensi dalam membentuk ruh diri adab, prilaku serta pribadi insane sesuai dalam koridor yang di tetapkan oleh Allah SWT $^{5}$.

Menurut Al Atas mengemukakan bahwa adab sejatinya harus dimiliki sebagai lambang dan symbol yang harus dimiliki guru pendidikan islam baik secara jasmani dan rohani ${ }^{6}$. Menurut Lane ta'dib diartikan sebagai:

He taught him wat is termed adb or good discipline of the mind and manners, he disciplined him or educated him well renderet him well bred wel manners polite instructed him in polite accomplishments.

${ }^{4}$ Al-Attas Syed Mohd. Tujuan dan Objektif Pendidikan Islam. (Kuala Lumpur: Dewan Bahasa dan Pustaka, 1992) hlm. 13.

${ }^{5}$ Abdullah Ishak, Pendidikan Islam dan Pengaruhnya di Malaysia. (Kuala Lumpur: Dewan Bahasa dan Pustaka, 1995) hlm. 56.

${ }^{6}$ Al-Attas Syed Mohd. Tujuan dan Objektif Pendidikan Islam. (Kuala Lumpur: Dewan Bahasa dan Pustaka, 1992) hlm. 14. 
Sementara Wehr menterjemahkan adab sebagai berikut,

To be well bred, well mannered, cultured, urbane and have refined tastes.

Kamus dewan mendefenisikan adab sebagai ahlak yang mustahabbah tingkah laku insana yang terpuji, khoir, sikap yang bagus. Menurut Hasan Langgulung dari segi pemakaian istilah ta'dib lebih cocok digunakan kepada pendidikan, karena ta'dib bukan hanya sekedar dipakai untuk peroses pembelajaran saja akan tetapi lebih daripada itu juga. Dan perlu diketahui bahwa istilah ta'dib dan istilah ta'dib duaduanya sangat erat kaitannya dan sangat erat dalam konteks islam ${ }^{7}$.

Nik Azis menyebutkan ta'dib memiliki nilai yang mutlak yang bisa mengokohkan keimanan yang bisa membangun jiwa seseorang muslim. Apabila manusia mampu berbuat kebajikan sesuai dengan yang Allah anjurkan barulah mereka dibsebut dengan berahlak mulia. Antara ta'dib dan ahlak sebenarnya sama tidak berbeda sama-sama bersumber dari wahyu. Sementara moral yang dimaksud adalah prilaku yang baik menurut norma dan kebiasaan yang disetujui oleh penduduk setempat. Moral hanya diterima oleh sekelompok yang terkait saja artinya walaupun benar baik betul, tapi nilainya tidak universal ${ }^{8}$.

Pada waktu yang sama moral hanya menekankan kepentingan manusia dengan alam sekitar agar tercipta hubungan baik dan harmonis. Sedangkan moral adalah buatan manusia yang hanya mengatur kepentingan masyarakat tertentu saja, maka moral berbeda dengan ta'dib karena moral tidak selalu dikaitkan dengan Allah serta yang bersifat metafisik, sedangkan ta'dib selalu dikaitkan dengan wahyu dan metafisik 9 .

Abdul Raof menyatakan bahwa ta'dib adalah kelakuan tata tertib dan marwah yang merangkum seluruh perbuatan yang lahiriyah hasil dorongan batiniyah dalam diri manusia. Ahlak terlahir dari undang-undang Allah SWT yang kepentinnya hanya untuk manusia agar manusia bisa hidup dengan rukun dan harmonis ${ }^{10}$.

Ta'dib menurut Shalaby adalah pendidikan diperingkat istana khususnya di masa khilafah bani abbasiah kala itu yang mengajar diberi gelar kehormatan sebagai muaddib. Para muaddib berfungsi mengasuh dan mendidik budi pekerti putra raja dan pembesar istana dengan ilmu pengetahuan dan kesastraan. Mereka memproleh keistimewaan dan penghormatan berbentuk harta benda dan tempat tinggal di istana. Mereka menikmati kekayaan dan kemakmuran sebagaimana yang dinikmati para pembesar istana, ini bermakna mereka lebih berfungsi sebagai guru peribadi kepada putra raja dan pembesar istana ${ }^{11}$.

Nilai ta'bid dalam islam bersifat mutlak, muktamad kekal abadi dan didasarkan pada keimanan yang kokoh. Seorang muslim akan membina dirinya dengan nilai ta'dib tadi karena ahlak lahir dari dorongan batiniyah diri manusia itu sendiri.

Secara ringkasnya cirri muaddib dalam kajian 5M ini adalah seperti berikut ini,

1) Memakai pakaian yang sopan dan pantas

2) Disipilin waktu

3) Lemah lembut dalam ucapan

4) Wibawanya terpancar

5) Memberikan pernghargaan atas kebaikan siswa

6) Bersifat tawadu' rendah hati

${ }^{7}$ Hasan Langgulung. Beberapa Tinjauan Dalam Pendidikan Islam. (Kuala Lumpur: Pustaka Antara, 1981) hlm. 35.

${ }^{8}$ Nik Azis. Potensi Intelek. Kuala Lumpur: (Dewan Bahasa dan Pustaka,1994) hlm.13.

9 Muhammad Yusuf. 2002. Aplikasi Teknologi dalam Pembelajaran. (Kuala Lumpur: UKM, 2002)

${ }^{10}$ Adbul Raof Dalif. Falsafah dan pendidikan. (Bangi: UKM, 1986) hlm. 23.

${ }^{11}$ Syalabi. Ahmad. Sejarah Pendidikan Islam. (Singapura: Pustaka Nasional, 1976) hlm. 39. 
7) Ceria

8) Memiliki ahlakul karimah

9) Memiliki tanggung jawab terhadap perkembangan siswa

10) Menjaga marwah

11) Menampilkan personality yang baik ${ }^{12}$.

\section{c. Murabbi}

Ungkapan murabbi berasal dari kata kerja tarbiyah yang artinya mendidik, membesarkan, memberi makan dan minum mendidik supaya berahlak mulia. Ibnu Mandhur dalam lisan arab mengemukakan bahwa perkataan tarbiyah sebagai raba al syai' yang memiliki makna sesuatu yang bertumbuh atau subur. Menurut Al-asma murabbi memiliki makna membesarkan, Al-Jawhari mendefinisikan murabbi sebagai memberi makan, membesarkan subur dan sebagainya ${ }^{13}$.

Pengertian tarbiyah nampaknya lebih luas dan umum karena melibatkan upaya dan tingkah laku manusia. Tarbiyah lebih menjurus kepada maksud ta'dib atau proses pembentukan tingkah laku atau ahlak.

Zawawi mengemukakan pendapatnya mengenai pengertian tarbiyah dari segi istilah sebagai berikut

1) Sebagai proses realisasi pembinaan manusia, pembentukan masyarakat yang sesuai dengan falsafah hidup agar memiliki keperibadian yang tinggi

2) Sebuah gagasan dan konsep yang saling berkaitan antara satu sama lain yang sesuai dengan ketentuan Allah SWT. Agar menjadi manusia berkepribadian

3) Memupuk fitrah dan bakat anak agar mereka bisa berkembang sesuai dengan kematangan yang dilalui oleh anak tersebut ${ }^{14}$.

Sementara Al-Nahlawy membagi membagi pengertian tarbiyah kepada tiga yaitu:

1) rabba yarubbu dibandingkan dengan madda yamuddu yang berarti memperbaiki, menguruskan kepentingan, menjaga mengatur dan memelihara dan meperhatikan sebagaimana syair Hasan bin Sabit yang berbunyi: sesunguhnya engkau sangat elok ketika muncul dihalaman istana pada hari keberangkatan mutiara putih jernih yang dipelihara oleh percampuran air samudera.

2) Rabiya yarba dibandingkan dengan kafiya yakfu yang berarti tumbuh dan berkembang berdasarkan ungkapan puisi Ibnu Arabi: barang siapa yang bertanya kepadaku, sesungguhnya tempat tinggalku di Mekkah dan disanalah aku tumbuh besar.

3) Berkembang dan bertambah berdasarkan firman Allah SWT. Dalam surah al-Rum ayat 39

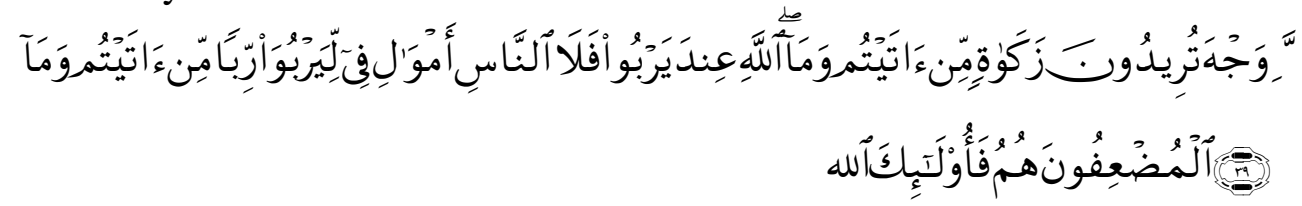

Artinya: apapun yang engkau berikan menjadi bertambah pada harta manusia, maka riba itu tidak menambah pada sisi Allah, dan zakat yang

\footnotetext{
${ }^{12}$ Syalabi. Ahmad. Sejarah Pendidikan Islam. (Singapura: Pustaka Nasional, 1976) hlm. 40.

${ }^{13}$ Al-Bustani. Munjit al-Tullab. (Beirut: Dar al-Fikr. Tahqiq: Syekh Abd. Aziz Abdullah, 1956) hlm. 21.

${ }^{14}$ Zawawi. Strategi Pengajaran Islam. (Selangor: Pajar Bakti, 1998) hlm. 45.
} 
kamu berikan untuk mencari rido Allah maka merekalah orang yang mendapatka ganjaran pahala yang besar.

Berdasarkan tiga pengertian ini, tarbiyah menurur al-Nahlawy mengandung paling tidak 3 point yang pertama menjaga, kedua, memelihara, dan ketiga mengembangkan bakat dan potensi kepada pencapaian kesempurnaan yang tinggi. Atan Long menerangkan bahwa istilah pendidikan mempunyai berbagai maksud dan tujuan.

Allah SWT ingatkan kita dalam surat al-Isra' ayat 24

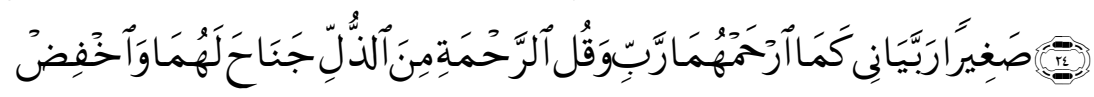

Artinya : yang kamu berikan ia menjadi bertambah pada harta manusia, maka riba itu tidak menambah pada sisi allah, dan zakat yang kamu berikan untuk mencapai keridoan Allah mak mereka yang mendapat gandaan pahala.

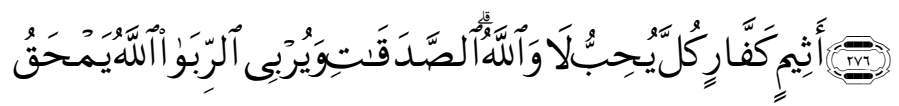

Artinya: Allah memusnahkan riba dan menyuburkan sedekah dan Allah tidak menyukai setiap orang yang tetap dalam kekafiran, dan selalu berbuat dosa.

$$
\text { 瞄 }
$$

Artinya: Fir'aun menjawab: bukankah kami telah mengasuhmu di dalam keluarga kami, waktu kamu masih anak-anak dan kamu tinggal bersama kami beberapa tahun

Maka jelaslah sudah bagi kita setelah mentelaah ayat-ayat diatas bahwa kita mengetahui bahwa tarbiyah itu lebih berarti kasih saying tumpuan kasih saying pemeliharaan yang sangat luarbiasa, memperhatikan perkembangan sosial dan fisik, jasmani dan rohani baik individu terlebih social.

Dari pembahasan yang sudah kita bahas maka paling tidak ada 13 sifat dari murabbi sebagai berikut

1) Menerapkan unsur ketauhidan

2) Mewujudkan hubungan yang erat dengan siswa ketika belajar

3) Mengajar dengan kasih sayang

4) Memberi hukuman yang mendidik bukan melukai

5) Menegur siswa dengan hikmah bukan menyindir atau mengungut

6) Menghargai pendapat siswa

7) Mengajar dengan panggilan hati

8) Mendampingi pelajar dengan penuh konsenterasi

9) Mengenal siswa dan keluarganya

10) Memberikan motivasi dengan berkesinambungan

11) Menggunakan bahasa yang pas dengan audiens sehingga mudah dipahami

12) Menerapkan nilai nilai keislaman

13) Menerapkan nilai nilai kemanusiaan ${ }^{15}$

${ }^{15}$ Atan Long. Psikologi Pendidikan. (Kuala Lumpur: Dewan Bahasa dan Bahasa, 1982) hlm. 29. 


\section{d. Mursyid}

Mursyid berasal dari bahasa arab yang memberi makna pemberi petunjuk dari kata kerja arsyada atau irsyad. Al quran dalam beberapa kali berbicara tentang mursyid, konsep irsyad menurut alquran mengandung makna yang menunjuki akan jalan yang baik, peminpin yang benar, serta sikot. Defenisi ini terkandung dalam Al quran diantaranya adalah,

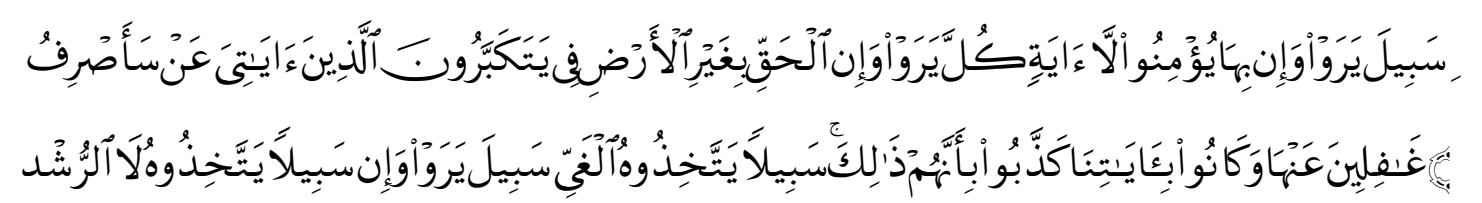

Artinya: Akan aku palingkan orang yang menyombongkan diri dari muka bumi tanpa alasan yang benar dari tanda kekuasaan ku. Mereka jika melihat ayat-ayatku mereka tidak beriman kepadanya. Dan jika mereka melihat jalan yang membawa kepada petunjuk, mereka tidak mau menempuhnya, tetapi jika mereka melihat jalan kesesatan, mereka terus menempuhnya, yang demikian itu adalah karena mereka mendustakan ayat ayat kami dan mereka selalu lalai daripadanya.(QS. Al a'raf: 146)

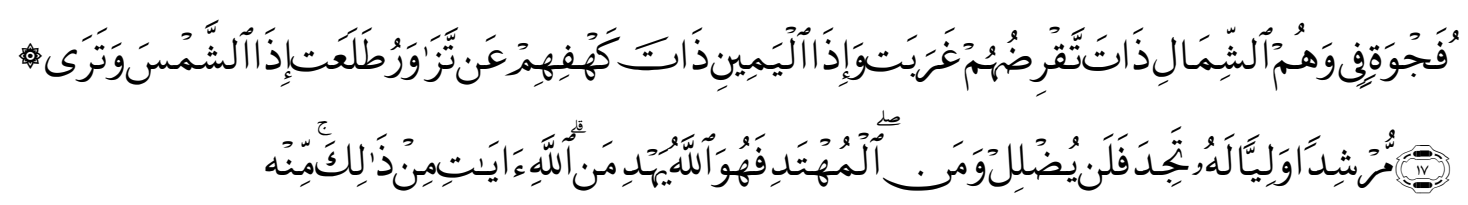

Artinya: dan kamu akan melihat matahari ketika terbit, condong dari gua mereka sebelah kanan, dan matahari terbenam menjauhi mereka sebelah kiri sedang mereka dalam tempat yang luas dalam gua itu. Itu adalah sebahagian dari tanda tada kekuasaan Allah. Maka dialah yang mendapat petunjuk, dan barang siapa yang diberi petunjuk oleh Allah, maka dialah yang mendapat petunjuk dan barang siapa yang disesatkannya maka kamu tidak akan mendapatkan seorang peminpin yang dapat member petunjuk kepadanya. (QS Al-Kahfi:17)

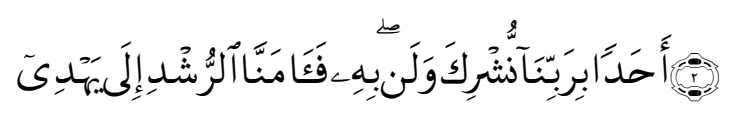

Artinya: yang memberi petunjuk kepada jalan yang benar, lalu kami beriman kepadanya, kami sekali-kali tidak akan empersekutukan seseorangpun dengan Tuhan kami. (QS.Al-Jin:2)

Memimpin kejalan yang benar, menasehati siswa, mengikuti, menjaga, petunjuk dan bimbingan, panduan, arahan, semua itu adalah proses dari Irsyad. Konteks ini konsep irsyad merujuk kepada kepeminpinan guru dalam mengajar, diantara cirri seorang mursyid dalam 5M yang perlu dimiliki oleh guru adalah:

1) Mengaplikasikan konsep musyawarah dalam keputusan

2) Mengaitkan tanggungjawab siswa sebagai khalifatullah

3) Membembing siswa membuat keputusan

4) Membuat suasana pembelajaran lebih menyenangkan

5) Menerapkan daya kepeminpinan dikalangan siswa 
6) Bertindak pantas dengan isu yang dihadapi oleh siswa

7) Membuat ide demi kemajuan semangat siswa untuk maju

8) Menunjukkan kepeminpinan berhikmah

9) Menunjukkan sikaf yang ramah kepada siswa, dan masyarakat

10) Memiliki sikap yang tegas

11) Bersikap adil kepada siswa ${ }^{16}$.

\section{e. Mu'allim}

Perkataan 'allama didefenisikan sebagai 'allama fulanan al-syai' ta'liman ja'alahu yuta'allamhu. Dalam itu morfologi arab apabila fi'il ditukarkan kepada wazan fa'ala, ini akan membawa arti banyak kali melakukan sesuatu ada pengulangan atau melakukan secara dabel.

Oleh karena itu perkataan 'allama berarti mengajar secara berulang-ulang proses ini melibatkan mu'allim atau guru, muta'allim siswa atau pelajar dan objek benda yang diajar. Adapun proses ta'lim memerlukan waktu yang lama dan dilakukan secara berulang-ulang atau diperlukan kepada ulangan yang berulangkali. Konsep ta'lim diuraikan dalam Alquran dalam beberapa ayat, adapun ayat yang berbicara tentang konsep ta'lim antara lain:

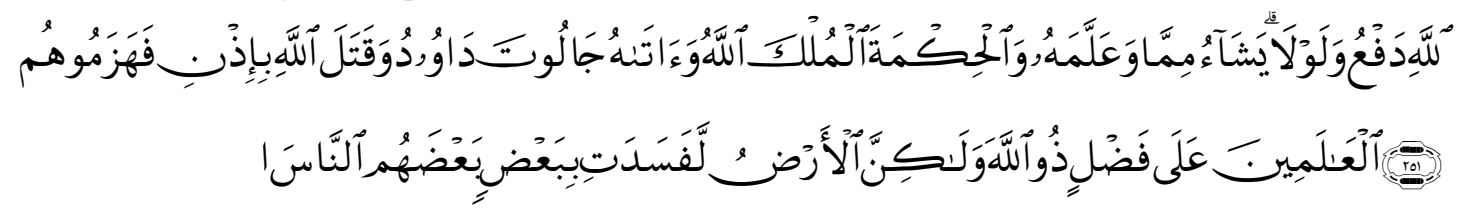

Artinya: Mereka tentara Thalut mengalahkan tentara jalud dengan izin Allah, kemudian Allah memberikan kepada Daud pemerintahan dan hikmah sesudah meninggalnya thalut dan mengajarkan kepada apa yang dikehendakinya. Seandainya Allah menolak keganasan ummat manusia dengan sebagian yang lain, pastilah rusak bumi ini. Tetapi Allah mempunyai karunia yang dicurahkan atas semesta alam.

(QS.Al-Baqarah:251)

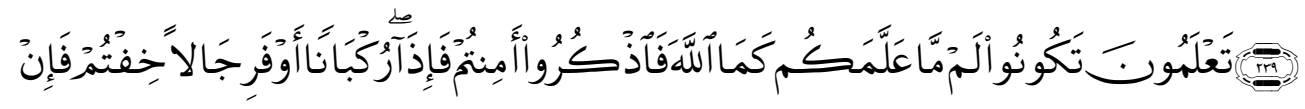

Artinya: Jikalau kamu takut dalam keadaan bahaya, maka shalatlah sambil berjalan atau dalam berkedaraan. Kemudian apabila kamu telah aman maka sebutlah Allah sebagaimana Allah telah mengajarkan kepadamu apa yang belum kamu ketahui. (QS.Al-Baqarah:239)

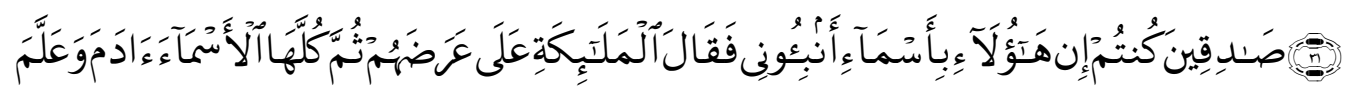

Artinya: dan dia yang mengajarkan kepada Adam nama-nama benda seluruhnya, kemudian mengemukakannya kepada para malaikat lalu berfirman. Sebutkanlah nama-nama benda itu jika kamu memang orang -orang yang benar. (QS.AlBaqarah:31)

16 Al-Attas Syed Mohd. Tujuan dan Objektif Pendidikan Islam. (Kuala Lumpur: Dewan Bahasa dan Pustaka, 1992) hlm. 16. 


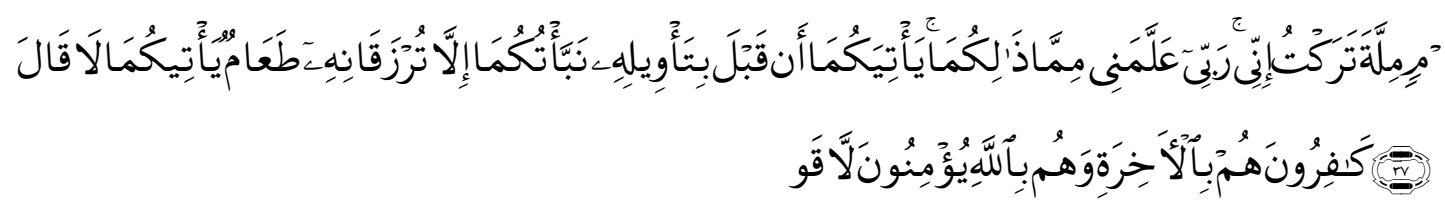

Artinya: Yusuf berkata: "Tidak disampaikan kepada kamu berdua makanan yang akan diberikan kepadamu melainkan Aku Telah dapat menerangkan jenis makanan itu, sebelum makanan itu sampai kepadamu yang demikian itu adalah sebagian dari apa yang diajarkan kepadaku oleh Tuhanku. Sesungguhnya Aku Telah meninggalkan agama orang-orang yang tidak beriman kepada Allah, sedang mereka ingkar kepada hari kemudian. (QS.Yusuf:37)

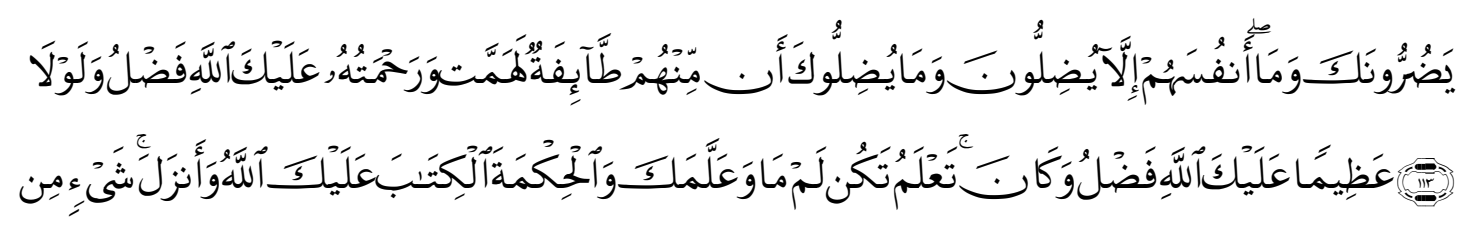

Artinya: Sekiranya kalau bukan karena karunia dan rahmat Allah kepadamu, tentulah segolongan dari mereka berkeinginan keras untuk menyesatkanmu. Tetapi mereka tidak menyesatkanmu melainkan dirinya sendiri, dan mereka tidak dapat membahayakanmu sedikitpun, dan juga Allah telah mengajarkan kepadamu apa yang belum kamu ketahui Dan adalah karunia Allah sangat besar untukmu. (QS. AlNisa: 113)

Perkataan 'allamahu dalam suroh Al-baqarah 251, 'allamakum albaqarah 31, 'allamani yusuf 37 dan 'allamaka alnisa 113 berarti mengajar dan diajarkan. Ringkasnya konsep Ta'lim boleh diartikan sebagai satu proses penyampaian, pemindahan, pengajaran dan pemberitahuan materi oleh seorang guru kepada siswanya. Proses ta'lim tersebut akan memberi warna pengembangan diri siswa sebagai insane soleh. Berikut ciri guru sebagai seorang mu'allim:

1) Menerapkan budaya penyelidikan

2) Mengaplikasikan ilmu dan menjelaskan idea

3) Mengaplikasikan pembelajaran mandiri

4) Menguasai kemahiran ceramah

5) Memperkaya sumber ilmu

6) Memahami konteks ilmu

7) Merangsang kemahiran berfikir kreatif dan kritis

8) Mengetahui isu-isu pendidikan yang terbaru

9) Menguasai uraian pembelajaran

10) Memadukan ilmu antar bidang

11) Menepati fakta

12) Menghargai dan meningkatkan ilmu

13) Memiliki dan menguasai ilmu

14) Selalu terbuka untuk menambah wawasan keilmuan ${ }^{17}$.

${ }^{17}$ Al-Attas Syed Mohd. Tujuan dan Objektif Pendidikan Islam. (Kuala Lumpur: Dewan Bahasa dan Pustaka, 1992) hlm. 18. 


\section{SIMPULAN}

Keunggulan guru pendidikan islam yang digariskan dalam konsep 5M adalah sesuai dengan pandangan para pakar dibidang pendidikan islam yang menyatakan bahwa antara sifat yang harus dimiliki oleh seorang guru adalah ketokohan dalam meminpin, kepribadian mulya, bersifat kasih saying dan berbudi luhur. Kebijaksanaan pendidikan dalam melaksanakan tanggungjawab membimbing dan meminpin anak didik, akan melengkapi diri mereka sebagai pendidik yang professional dan berwibawa. Profesionalisme ini mampu menjadikan golongan pendidik sebagai contoh terbaik dalam mewujudkan tujan pendidikan secara kaffah.

\section{DAFTAR PUSTAKA}

Raof, Abdul. Falsafah dan pendidikan. Bangi: UKM, 1986.

Ishak, Abdullah. Pendidikan Islam dan Pengaruhnya di Malaysia. Kuala Lumpur: Dewan Bahasa dan Pustaka, 1995.

Al-Attas, Syed. Mohd. Tujuan dan Objektif Pendidikan Islam. Kuala Lumpur: Dewan Bahasa dan Pustaka, 1992.

Al-Bustani. Munjit al-Tullab. Beirut: Dar al-Fikr. Tahqiq: Syekh Abd. Aziz Abdullah, 1956. Ibrahim, Anis. Al-Mu'jam al-Wasit al-Mu'jam al-Lughawi: Kairo, 1972.

Long, Atan. Psikologi Pendidikan. Kuala Lumpur: Dewan Bahasa dan Pustaka, 1982.

Halstead, Towards. AUnified View of Islamic Edacuation. Cambridge: Cambridge University Press 1995.

Hashim, Rosnani. Educational Dualism in Malaysia. Kuala Lumpur: Oxford University Press, 1996.

Langgulung, Hasan. Beberapa Tinjauan Dalam Pendidikan Islam. Kuala Lumpur: Pustaka Antara, 1981.

E.W. Lane. English-Arabic Lexicon. Cambridge: Cambridge University Press, 1984.

Yusuf, Muhammad. Aplikasi Teknologi dalam Pembelajaran. Kuala Lumpur: UKM, 2002.

Azis, Nik. Potensi Intelek. Kuala Lumpur: Dewan Bahasa dan Pustaka, 1994.

Syalabi, Ahmad. Sejarah Pendidikan Islam. Singapura: Pustaka Nasional, 1976.

Wehr. H. A dictionary of Modern Written Arabic. Inggris: Otto Harrassowitz, 1971.

Zawawi. Strategi Pengajaran Islam. Selangor: Pajar Bakti, 1998. 